(c) Elsevier/INRA

Original article

\title{
Herdbook analyses of the Asturiana beef cattle breeds
}

\author{
J Cañón ${ }^{1}$, JP Gutiérrez ${ }^{1}, S$ Dunner ${ }^{1}$, F Goyache $^{2}$, M Vallejo ${ }^{1}$ \\ ${ }^{1}$ Facultad de Veterinaria, Departamento de Producción Animal, 28040 Madrid; \\ ${ }^{2}$ Centro de Selección Animal (CENSA), Sección de Genética, Somió, Asturias, Spain
}

(Received 16 March 1993; accepted 12 October 1993)

\begin{abstract}
Summary - Data from 2 Asturiana breeds' herdbooks were analysed to study their genetic structure. Herds were assigned to 3 levels by the use of herd sires. Generation intervals averaged 5.3 (Casina) and 5.4 (Carreñana) yr, and for both breeds sires were significantly younger than dams. Determination of the important herds shows the contribution of Caso county $(60 \%)$ to the total herd appearance of the Casina breed. The overall mean Wright's inbreeding coefficients were 1.2 and $0.2 \%$ and the increases of inbreeding level per generation were 0.7 and $0.24 \%$ for Casina and Carreñana, respectively. Those low values of inbreeding increase can be partially explained by a relatively low centralization reflecting a high degree of diversity.

pedigree / herdbook / population structure / beef cattle

Résumé - Analyses des livres généalogiques des races bovines, asturiennes à viande. $L$ 'information des livres généalogiques de 2 races asturiennes a été analysée pour connaître leur structure génétique. Une division des troupeaux en 3 groupes est réalisée en fonction de l'utilisation des taureaux. Les intervalles entre générations s'élèvent à 5,3 ans chez la race Casina et 5,4 ans chez la Carreñana et dans les 2 cas les mâles en service sont plus jeunes que les femelles. La détermination des troupeaux les plus importants montre la contribution de la région du Caso (60\%) à l'ensemble des troupeaux apparaissant en race Casina. Le coefficient de consanguinité moyen total de Wright est de 0,7\% pour la Casina et de 0,24\% pour la Carreñana. Les taux très bas d'augmentation de la consanguinité peuvent en partie s'expliquer par une centralisation relativement faible, qui reflète une grande diversité.
\end{abstract}

pedigree / livre généalogique / structure de population / bovin à viande 


\section{INTRODUCTION}

Asturiana de los Valles (Carreñana or Asturiana occidental) and Asturiana de la Montaña (Casina or Asturiana oriental) (Mason, 1988) are 2 local beef cattle breeds located mainly in Asturias (Spain). The Cantabric branch is the common origin of both breeds which are very similar to the French Parthenais and Tarentais breeds. Animal sizes are quite different for both breeds. For instance, the mature weight of Casina cows is $350-400 \mathrm{~kg}$ while the mature weight of Carreñana cows is $550-600 \mathrm{~kg}$.

The Casina breed is distributed in the eastern Asturias, around the National Park of Covadonga. The Caso's Breeders Society started in 1910 and in 1929 selection within Casina populations was organized by establishing the herdbook and the milking recording scheme. Production of milk to transform into cheese was the objective for this breed and no more than 5000 cows were included in the recording scheme. These activities stopped in 1936 because of the civil war. In the 1940s the introduction of the imported Brown Swiss breed began causing a strong recession in population size. In 1978 the herdbook was refounded by the Breeder Association (ASEAMO) including at present 136 breeders and 2831 animals. The use of AI is marginal, less than $2 \%$ of the matings.

Even though Carrenana is distributed in the central and western part of Asturias, genetically important herds also exist outside the region (Pais Vasco, Castilla-León, Castilla-La Mancha, Cantabria and Extremadura). At the begining of this century the population size was around 100000 animals but introduction of Friesians after the 1920s and Brown Swiss in the 1940s reduced the census to 40000 by the end of the 1970s. At present, the population size is around 56000 and 15000 animals are registered in the herdbook created in 1976; the Breeder Association (ASEAVA) includes about 1200 breeders grouped across 13 performance recording nucleus. Their breeding objective is post-weaning growth efficiency while maintaining calving difficulty incidence at a constant level. AI within the breed is increasing and is around $20 \%$. Most of the semen doses demand $\left(2.5 \times 10^{5}\right.$ to $\left.3.0 \times 10^{5}\right)$ comes from Holstein farmers to increase the added value of calves.

An important characteristic of these breeds is the lean carcass they produce, with lower fat percentage than most of the European beef cattle breeds (Vallejo et al, 1992).

However, although 25 cattle breeds are officially recognized in Spain (Mapa 1981), herdbook studies for only 2 cattle breeds have been carried out: Avileña (Vasallo et al, 1986) and Pirenaica (Altarriba and Ocariz 1987).

The objective of this work was to use data from the Asturiana Societies' herdbooks to determine the structure and organization of these breeds.

\section{MATERIAL AND METHODS}

Evolution of the herds and animals registered in the herdbooks and distribution of herd size are shown in tables I and II, and in figure 1.

The information registered in the herdbook indicated that about 2800 animals of the Casina breed were distributed across 136 herds, from which 170 were parent 
Table I. Evolution of numbers of breeders and animals registered in the Breeder Associations.

\begin{tabular}{cccccc}
\hline & Casina & & & \multicolumn{2}{c}{ Carreñana } \\
\cline { 6 - 6 } Year & Breeders & Animals & & Breeders & Animals \\
\hline 1986 & 106 & 1402 & 481 & 4013 \\
1988 & 108 & 2107 & 747 & 8156 \\
1990 & 126 & 2279 & 921 & 12593 \\
1992 & 136 & 2831 & 1193 & 15536 \\
\hline
\end{tabular}

Table II. Number of births per period of time.

\begin{tabular}{lcc}
\hline Period of time & Casina & Carreñana \\
\hline$\leqslant 1978$ & 416 & 897 \\
$1979-1982$ & 529 & 2038 \\
$1983-1986$ & 679 & 4591 \\
$>1986$ & 1065 & 5761 \\
\hline
\end{tabular}

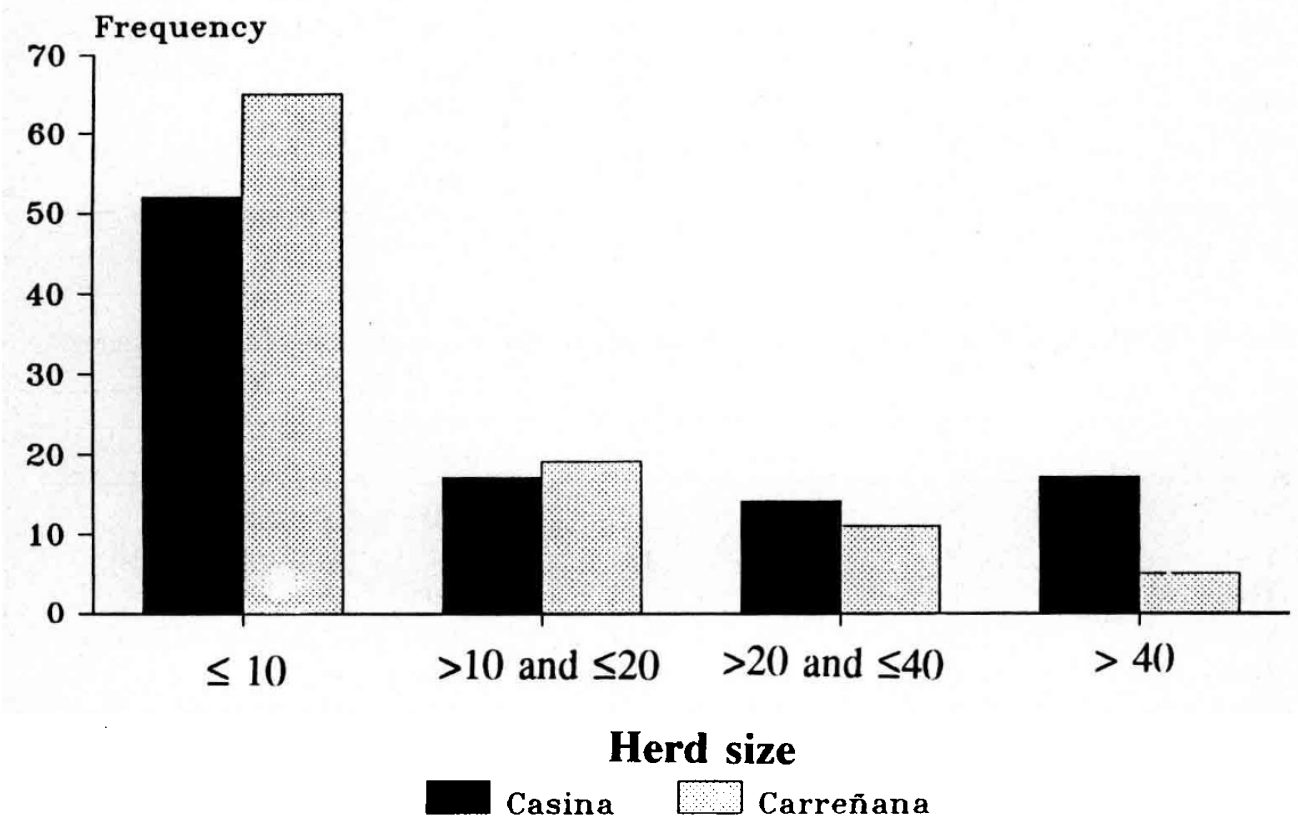

Fig 1. Distribution of herd size for Casina $\square$ and Carreñana 
males and 777 parent females. A total of 15500 animals of the Carrenana breed were distributed across 1200 herds, from which 913 were parent males and 4090 parent females. This information was used to compute the following items: genetically important herds; effective number of herds ; generation length; and inbreeding and relationships.

The structure of the population can be observed by describing the use of herd sires. The herds can be classified into: a) nucleus herds; b) multiplier herds; and c) commercial herds. Tables III and IV were built considering only herds with at least 6 registered animals following the classification given by Vasallo et al (1986), where herds are classified according to the degree of confidence of the breeders in their own genetics. According to these authors, breeders of nucleus herds never purchase bulls, but they sell bulls; breeders of multiplier herds use purchased bulls and also sell bulls to other multipliers or commercial herds; and breeders of commercial herds never sell bulls. This way of classifying herds is conceptually different from what Stewart (1952 and 1955) and Barker (1957) describe, in which movement of bulls within the nucleus is possible and in which there is no exchange of bulls between multiplier herds.

Table III. Herds of Casina classified according to the origin and use of the herd sires.

\begin{tabular}{lccrrl}
\hline $\begin{array}{l}\text { Using purchased } \\
\text { bulls }\end{array}$ & $\begin{array}{c}\text { Using own } \\
\text { bulls }\end{array}$ & $\begin{array}{c}\text { Selling } \\
\text { bulls }\end{array}$ & $\begin{array}{c}\text { No of } \\
\text { herds }\end{array}$ & $\begin{array}{c}\text { \% purchased } \\
\text { bulls }\end{array}$ & \\
\hline No & Yes & Yes & 4 & 0 & (Nucleus herds) \\
Yes & Yes & Yes & 17 & 59 & (Multiplier herds) \\
Yes & No & Yes & 5 & 100 & \\
Yes & Yes & No & 6 & 65 & (Commercial herds) \\
Yes & No & No & 13 & 100 & \\
\hline
\end{tabular}

Table IV. Herds of Carreñana classified according to the origin and use of the herd sires.

\begin{tabular}{lccccl}
\hline $\begin{array}{l}\text { Using purchased } \\
\text { bulls }\end{array}$ & $\begin{array}{c}\text { Using own } \\
\text { bulls }\end{array}$ & $\begin{array}{c}\text { Selling } \\
\text { bulls }\end{array}$ & $\begin{array}{c}\text { No of } \\
\text { herds }\end{array}$ & $\begin{array}{c}\text { \% purchased } \\
\text { bulls }\end{array}$ & \\
\hline No & Yes & Yes & 8 & 0 & (Nucleus herds) \\
Yes & Yes & Yes & 125 & 47 & (Multiplier herds) \\
Yes & No & Yes & 11 & 100 & \\
Yes & Yes & No & 17 & 63 & (Commercial herds) \\
Yes & No & No & 30 & 100 & \\
No & Yes & No & 3 & 0 & (Herds disconnected) \\
\hline
\end{tabular}

The structure of the population has also been analysed using Robertson's method (1953) for determining the effective number of herds supplying sires, grand sires and great-grand sires and comparing them with the actual number of herds 
supplying sires, grand sires and great-grand sires which gives some information on the concentration of origins.

Genetically important herds were analysed by the 3 methods proposed by Barker (1957): 1) total appearances as males; 2) appearances of each herd in the sire-ofsire line; and 3) total score of males appearances: an appearance in the parental generation scored 4, an appearance in the grandparental generation scored 2, and an appearance in the great-grandparental scored 1. The original method proposed by Wiener (1953) to analyse breed structure was also used. In order to apply this method, the description given by Barker (1957) was followed.

Generation length was computed for the 4 pathways (sire-son, sire-daughter, dam-son and dam-daughter) using birth dates of registered animals together with those of their sires and dams.

Wright's inbreeding coefficients for all registered bulls and cows were estimated using a modified Quaas' computing strategy (Gutierrez et al 1990) and an average coefficient of relationship between bulls in each population was computed. The known generations number represents the maximum number of generations known and is obtained by looking for the furthest known ancestor. The amount of available pedigree information is described for the 2 breeds in table $\mathrm{V}$.

Table V. Pedigree information available for the 2 breeds expressed as percentages.

\begin{tabular}{rlcr}
\hline Furthest known ancestor number & Casina & Carreñana \\
\hline 0 & (Base Population) & 40.8 & 52.3 \\
1 & (One parent known) & 13.2 & 21.9 \\
2 & (One grandparent known) & 14.2 & 14.0 \\
3 & (One great-grandparent known) & 13.5 & 5.7 \\
4 & (One great-great-grandparent known) & 14.8 & 5.0 \\
$\geqslant 5$ & (Rest) & 3.4 & 1.1 \\
\hline
\end{tabular}

\section{RESULTS AND DISCUSSION}

\section{Casina breed}

Four herds were assigned to the nucleus level, 22 herds to multipliers and 19 herds were assigned to the commercial level (table III). Of the bulls purchased by the breeders of multiplier herds $35 \%$ comes from what we call nucleus herds and $65 \%$ comes from other multiplier herds. Of bulls purchased by breeders of commercial herds, $17 \%$ come from nucleus herds and $83 \%$ come from multiplier herds. Although there is a low number of herds considered at the top of the structure, the estimates of the effective number of herds supplying sires, grand sires and great-grand sires indicate that a relatively large number of herds contribute with grand sires and great-grand sires. Two animals taken at random from the pedigree book have a similar probability of having their great-grand sires from the same herd if these ancestors had been contributed equally by 9 herds. This relatively high degree of 
diversity of origins for the reproductive animals is also confirmed by comparing the actual and effective number of herds (table VI). Herds in the Caso county have contributed to more than $60 \%$ of the total appearances. This highlights the importance of this county in which the origin of this breed is believed to be (table VII). The rank of important herds does not significantly change between the 3 different methods of Barker. The values of rank correlation are greater than $0.90(p<0.01)$. Dividing the whole period of time in 3 parts $(<1983,1983-1987$ and $>1987$ ) and using method 2 , which can be considered as the most precise (the total number of appearances, method 1, can depend on a previous appearance of that herd in the same pedigree), the value of rank correlation between periods of time is $0.94(p<0.01)$ showing that the importance of the herds is unchanged with time. This can also be confirmed using a variant proposed by Wiener (1953). This method gives the evolution of the importance of a herd in terms of change in genetic contribution per generation and represents the contribution of a herd based on the number of appearances of this herd, independently of an earlier chronological appearance (table VIII). The genetic contribution of the 6 major herds to registered females is $47.5 \%$ and the relative order is quite similar to that reflected in table VII.

Table VI. Effective and actual number of herds.

\begin{tabular}{lcccccccc}
\hline & \multicolumn{2}{c}{ Sires } & & \multicolumn{2}{c}{ Grand sires } & & \multicolumn{2}{c}{ Great-grand sires } \\
\cline { 2 - 3 } & Casina & Carreñana & & Casina & Carreñana & & Casina & Carreñana \\
\hline Effective & 22 & 136 & & 9 & 73 & & 9 & 28 \\
Actual & 45 & 277 & & 18 & 76 & & 6 & 16 \\
\hline
\end{tabular}

Table VII. Large herds of Casina breed for (1) total appearances as males, (2) appearances of each herd in the sire-of-sire line, and (3) total score of males appearing (expressed as percentages).

\begin{tabular}{llcclll}
\hline Herd & County & (1) & (3) & Herd & \multicolumn{2}{c}{ County } \\
\hline Alfredo Armayor & Caso & 36 & 36 & Alfredo Armayor & Caso & 33 \\
Rogelio González & Caso & 26 & 25 & Manuel Cueto & Ponga & 28 \\
Manuel Cueto & Ponga & 19 & 19 & Rogelio González & Caso & 22 \\
Jose Ramon Concha & Cangas & 6.5 & 7.4 & Alousa and Ramon Vega Caso & 7.3 \\
El Abuelo, SA & Piloña & 6.5 & 6.8 & Jose Ramon Cocha & Cangas & 6.5 \\
Alouso and Ramon Vega & Caso & 6.0 & 5.4 & El Abuelo, SA & Piloña & 2.8 \\
\hline
\end{tabular}

Generation intervals, which averaged $5.3 \mathrm{yr}$, are significantly higher $(50 \%)$ for dams (6.35) than for sires (4.19), and sires of males (or females) are younger than their mates (table IX). It seems evident that the use of sires to breed bulls is performed before any progeny information is available. This could be a sign that breeders are using type and/or pedigree information for selecting bulls. Bulls and cows are selected from dams with similar age which means a similar amount of 


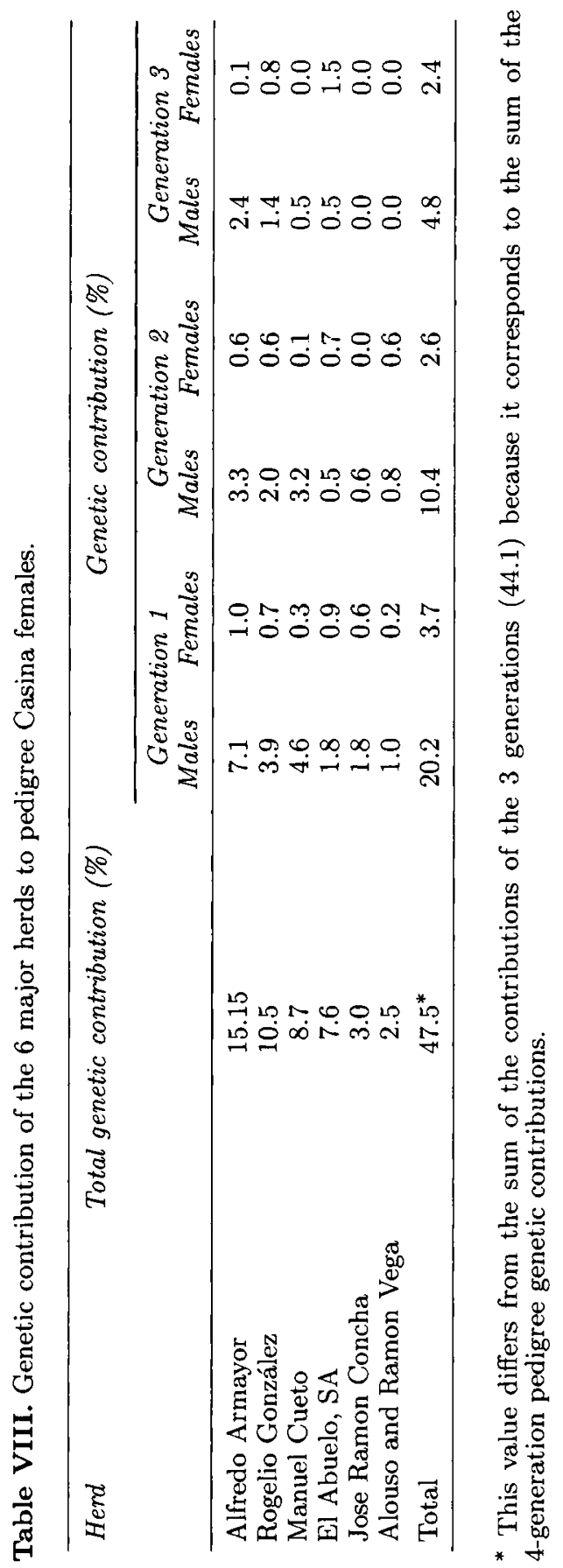


information. Similar generation interval differences are found for the Avileña breed in Spain (Vasallo et al, 1986) and for other breeds such as the Shorthorn in Australia (Herron and Pattie, 1977) or the Hereford in UK (Özkütük and Bichard, 1977) and very similar values have been published for Poll Hereford in Australia (Herron 1978; Toll and Barker 1979).

Table IX. Generation intervals for pedigree Asturiana beef cattle breeds.

Asturiana breeds

\begin{tabular}{lcccc}
\cline { 2 - 4 } Parent-offspring & $N$ & Casina & $N$ & Carreñana \\
\hline Sire-son & 550 & $4.3 \pm 0.07^{\mathrm{a}}$ & 2111 & $5.0 \pm 0.06^{\mathrm{a}}$ \\
Sire-daughter & 843 & $4.1 \pm 0.05^{\mathrm{b}}$ & 3418 & $4.8 \pm 0.04^{\mathrm{b}}$ \\
Dam-son & 619 & $6.4 \pm 0.11^{\mathrm{c}}$ & 2153 & $6.0 \pm 0.06^{\mathrm{c}}$ \\
Dam-daughter & 911 & $6.3 \pm 0.10^{\mathrm{c}}$ & 3506 & $5.8 \pm 0.05^{\mathrm{d}}$ \\
Weighted average & & $5.30 \pm 0.08$ & & $5.4 \pm 0.05$ \\
\hline
\end{tabular}

Means with different letters are significantly different $(p<0.05)$.

The overall mean Wright's inbreeding coefficient was $1.2 \%$ and, when only animals with at least 3 pedigree generations registered are considered, the level of inbreeding averaged $2.5 \%$. Although the Casina breed was $1.7 \%$ more inbred in 1991 than it was in 1978, which supposes an increase of $0.7 \%$ per generation, the inbreeding level does not increase significantly during the last $9 \mathrm{yr}$ (1.7 generations), whereas the number of pedigree generation does (table $\mathrm{X}$ ). The average coefficient of relationship between bulls was $0.8 \times 10^{-2}$.

Conservation efforts must be applied to this breed as the real population size is closer to 1400 females than to the number of 7568 given by the MAPA (1989). The number of 1400 can be obtained by considering that the average annual registration of females for Casina was 143 for the last $4 \mathrm{yr}$, and that all females coming from pure mates are registered, and by assuming a replacement index of $10 \%$.

\section{Carreñana breed}

The number of herds considered as nuclei were $8 ; 136$ herds can be considered as multipliers as their breeders purchase and sell bulls to other herds; and 47 herds could be considered as commercial since their breeders do not distribute bulls out of their own herd (table IV). Five per cent of the bulls purchased by breeders of herds come from nucleus herds while breeders of commercial herds only buy bulls from multiplier herds. The low percentage of bulls purchased into nucleus herds is a consequence of the relatively low size of those herds with an average of 12 animals registered.

The numerical description of the breed structure given in table VI shows the effect of centralization, which is comparatively less marked with regard to other beef cattle breeds, particularly in comparison with the Casina breed. The greater values for grand sires and great-grand sires levels reflect a higher degree of goal diversity 
Asturiana beef cattle breeds

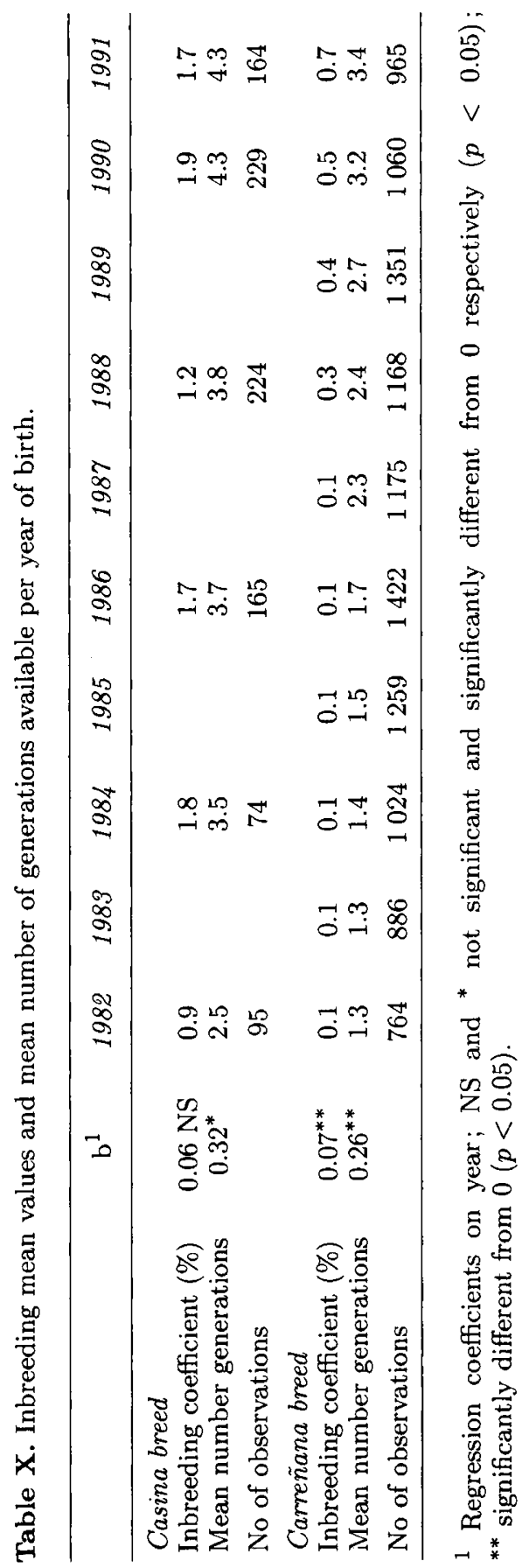


between breeders. This can also be argued by comparing the number of herds supplying sires (grand sires or great-grand sires) with the effective number of herds supplying sires (grand sires or great-grand sires). Results for genetically important herds also reflect this diversity. Geographic dispersion of the most important herds is difficult to justify by looking at the current knowledge on the genetic herd levels.

The average generation length was $5.4 \mathrm{yr}$ and generation lengths for the 4 pathways of the parent-offspring are shown in table IX.

The ages of the sires at the birth of offspring were significantly $(p<0.05)$ lower than the ages of dams, 4.9 vs 5.9. The ages of sires varied among birth years of progeny and the analysis showed a trend towards the use of older animals $(b=0.08)$ since 1975. Although this is a smooth trend, it seems evident that, as before, the use of sires to breed bulls or cows is made before any progeny information is available. Different $(p<0.05)$ herd practices in selecting sires were found since the age of sires also varies between herds in which progeny were born. Similar figures apply for dams. The ages of dams varied between years of birth of progeny and herds.

The overall mean inbreeding coefficient was $0.2 \%$. When including only animals with more than 2 pedigree generations known, the average was $0.7 \%$. The increase of inbreeding per generation was $0.24 \%$, this value being significantly different from 0 (table $\mathrm{X}$ ) and the average coefficient of relationship between bulls was $0.5 \times 10^{-3}$. These results show that a strict control on the relationships between the animals to be mated is not very necessary.

It can be concluded that most of the parameters estimated are typical in developing breeds. The results show that if any selection has been practiced, it was based on type and/or pedigree information, and that from the generation length observed ( $>5 \mathrm{yr}$ ) rather low genetic progress within each breed can be expected to be observed at present. Genetic evaluation for economic traits began 2 yr ago and preliminary estimates of genetic variability for the most important characters (birth, weaning and yearling weights) show high values, which could be a consequence, as stated earlier, of the lack of previous selection.

\section{ACKNOWLEDGMENT}

This work was partially supported by a grant from the CICYT, no AGF92-0852 and from ASEAVA. We also would like to thank one of the referees for his comments which led to an improved presentation.

\section{REFERENCES}

Altarriba J, Ocariz JM (1987) Estudio genético-reproductivo de la raza Pirenaica a partir del Registro Genealógico de Navarra (Genetic studies of the Pirenaica pedigree herdbook in Navarra). ITEA 7, 67-69

Barker JSF (1957) The breed structure and genetic analysis of the pedigree cattle breeds in Australia. I. The Jersey. Aust J Agric Res 8, 561-586

Gutierrez JP, Cañon J, Rico M (1990) Aplicación de un método modificado de cálculo del coeficiente de consanguinidad en una muestra del ganado frisón Español (Computing inbreeding coefficient in a Spanish Holstein sample). Arch Zootec 39, $3-8$ 
Herron ND (1978) The breed structure and genetic analysis of the pedigree Sahiwal breed in Australia. Aust J Agric Res 29, 381-393

Herron ND, Pattie WA (1977) Studies of the Australian Illawara Shorthorn breed of dairy cattle. I. Breed Structure. Aust J Agric Sci 28, 1107-1117

Mason IL (1988) World Dictionary of Livestock Breeds. 3rd ed CAB Int Oxon, UK Ministerio de Agricultura, Pesca y Alimentación (MAPA) (1981) Catálogo de Razas Autóctonas Españolas. II Especie Bovina. Ministry of Agriculture, Fish and Food. Madrid

Ministerio de Agricultura, Pesca y Alimentación (MAPA) (1989) Anuario de Estadistica Agraria. Ministry of Agriculture, Fish and Food. Madrid

Özkütük K, Bichard M (1977) Studies of pedigree Hereford cattle breeding. 1. Herdbook analysis. Anim Prod 24, 1-13

Robertson A (1953) A numerical description of breed structure. J Agric Sci 43, 334-336

Stewart A (1952) The expansion and structure of the New Zealand pedigree Jersey breed. Proc NZ Soc Anim Prod 12, 32-39

Stewart A (1955) Expansion and structure of the New Zealand pedigree Ayrshire breed, 1910 to 1950. NZ Sci Technol 36, 493-505

Toll GL, Barker JSF (1979) Genetic history of the pedigree poll Hereford breed in Australia: effect of the importation ban. Aust J Agric Sci 30, 767-777

Vallejo M, Alonso L, Revuelta JR, Cima M, Cañon J (1992) Características de las canales de las razas bovinas asturianas I. Bases cuantitativas de la valoración subjetiva. Arch Zootec 40, 335-357

Vasallo JM, Diaz C, Garcia-Medina M (1986) A note on the population structure of the Avileña breed of cattle in Spain. Livest Prod Sci 15, 285-288

Wiener G (19533) Breed structure in the pedigree Ayrshire cattle population in Great Britain. J Agric Sci 43, 123-130 